\title{
Ethical Banking Determinants across Nations: A Meta-Analysis
}

\author{
Olalekan Usiobaifo Asikhia \\ Graduate School of Business Leadership \\ University of South Africa, South Africa \\ asikhou@unisa.ac.za
}

\begin{abstract}
Ethical issues in banking practice have become an important aspect that the nations of the world should take into consideration, especially in the light of incessant bank failures with concomitant loss of customers' deposits. It now becomes imperative to study the determinants of ethical banking in order to create an enabling environment for the practice and sustenance of customers' confidence. Several studies were analyzed and it was found that leaders' characteristics, the organizational characteristics and the sales force characteristics have a positive impact on ethical behaviour as well as on job security. Some selected organizational, cognitive and affective dimensions were also found to affect the ethical practices of banks. Relevant recommendations and policy implications were made.
\end{abstract}

Keywords: Ethical banking, determinants, cognitive dimensions, organizational factors, Affective dimensions, nations

\section{Introduction}

Banks as financial intermediary agents are expected to execute their functions in such a way that they promote confidence and ensure stability. Banks help to bring borrowers and lenders together, and this can be successfully done through good management of credit, liquidity and interest rate risks, amongst others. The banks are primarily funded by depositors and they have to ensure that the trust that these depositors place on them are not dashed and that every effort is made to minimize the risks to them. However, this has not been the case, with incessant bank crises and failures around the world. Chami \& Fullenkamp (2002) argue that trustworthiness is crucial for the survival of any bank. The banks being intermediaries between the depositors and creditors are expected to have honesty, integrity, social responsibility, accountability and fairness in order to forestall failures. Banks must therefore be able to act in a way that merits public trust, confidence and a good reputation by infusing values such as honesty, trust, respect and fairness into the decision-making process. It is expected that banks should base their behaviour on ethical criteria with the understanding that financial yield depends on the trend of the real economy and not on any kind of manipulation. Bozovic (2007) opines that ethics belong to philosophy because it studies human behaviour from a moral perspective. Most often the focus of ethics is community-centred and the morality of ethics is seen from the universal welfare of the community - hence McKinsey (2010) asserts that a company's ability to create value is a critical measure of performance when it takes the interests of all the stakeholders into consideration.

Ethical banking is about obtaining social and economic profitability, adding value and supplying the needed benefits to the stakeholders. Cowton (2002) advances the three components of ethical banking as integrity (which generates trust), responsibility (lending appropriately and avoiding financial exclusion of any segment of the society) and finally, affinity (establishing closer relationships between depositors and borrowers). San-Jose and Retolaza (2008) identify some basic characteristics that differentiate ethical banking from traditional banking as the transparency and participation of savers in the decision about the investment of their savings and the location of funds in projects with an added social value. To further substantiate this, Barbu and Boitan (2009) assert that the major characteristic of ethical banks is that they operate with a clear set of ethical values, known, accepted and respected at all the hierarchical levels. And such banks pursue both financial and social gains, believing that investment decisions belong to customers in choosing the ethical projects to be financed by their funds. They publish lists of financed investment projects and they finance projects with a positive influence on the society and environment. Baranes (2009) believes 
that ethical banks consider the non-economic consequences of their operations as just as important as the economic ones. They pay attention to the vulnerable sectors of the society as well as hinge their decisions on a full disclosure of information towards all the stakeholders.

The omission of ethical practice in banks across the world has not only limited economic growth but has resulted in the infliction of pain on depositors and other stakeholders. Beim (2001) asserts that any of these four agents, depositors, government, external lenders and intergovernmental financial institutions, can trigger a crisis in the banks due to their roles as suppliers of banks' funds. He establishes that most banks and financial institutions' scandals stemmed from a lack of trust and reputation. The vulnerability dimension of trust is overbearing between the bank managers and the shareholders, as well as the bank managers and the regulatory bodies. In Turkey, 22 banks were taken over by the Savings Deposits Insurance Fund (SDIF) between the years 1997 to 2003. The precarious situation worsens during the last quarter of 2000 and 2001 due to the highly volatile regulatory environment. In Nigeria, Sanusi (2010) reports all kinds of malpractices which resulted in most of the depositors' monies ending up in private pockets, with CEOs setting up special purpose vehicles to lend money to themselves for stock price manipulation or for the purpose of acquiring estates all over the world. In his words: "One bank borrowed money and purchased private jets which were later discovered were registered in the name of the CEO's son. In another bank the management set up 100 fake companies for the purpose of perpetrating fraud. A lot of the capital supposedly raised by these so-called 'mega banks' was fake capital financed from depositors' funds. $30 \%$ of the share capital of Intercontinental Bank was purchased with customer deposits. Afribank used depositors' funds to purchase $80 \%$ of its IPO. It paid N25 per share when the shares were trading at N11 on the Nigerian Stock Exchange (NSE) and these shares later collapsed to under N3. The CEO of Oceanic Bank controlled over 35\% of the Bank through SPVs borrowing customer deposits. The collapse of the capital market wiped out these customer deposits amounting to hundreds of billions of naira" (Sanusi, 2010:7). In Kenya, Mathenge (2013) reports that the Kenya financial sectors continue to witness several unreported cases of unethical conducts, with bank workers having the focus to raise money for themselves instead of offering products and services that could raise the living standard of the people.

The various experiences of banks' crises across nations of the world and the concomitant high numbers of banking people prosecuted provokes a challenging question of morality and the ethical background of such institutions. Kjonstad and Willmott (1995), Rossouw and Vuuren (2003) and Ten Bos and Willmot (2001) argue that while the prescription of moral norms may ensure compliance it does not guarantee morally sound behaviour. Bauman and Tester (2001:46) say "being moral means knowing that things may be good or bad". But it does not mean knowing, let alone knowing for sure, which things are good and which things are bad. It implies that ethics could be enacted in situations of ambiguity where dilemmas and problems will be dealt with without the comfort of consensus or certitude. The paucity of researchers that compare these unfortunate incidences across nations in order to generate in-depth thoughts and furnish lasting solution is worrisome. It is in this light that this study investigated the ethical banking determinants that can positively influence and reposition the banking industry across nations. Specifically, the study determined the Social Value Added Lending (SVA-L) ratio and the Avoiding Social Exclusion Lending (ASE-L) ratio of the banks, the degree of ethical compliance by the banks, and finally, it evaluated the value system, loan effectiveness, equality in service provision and social factors relationship with ethical practice. The major research questions answered were: What are the Social Value Added Lending (SVA-L) ratio and the Avoiding Social Exclusion Lending (ASE-L) ratio of the banks; what is the degree of ethical compliance of the banks; and how do value systems, loan effectiveness, equality in service provision and social factors relate to ethical practice.

\section{Conceptual Clarifications}

Ethics defines a set of rules that guide people through the decision-making process in order to enable them to distinguish between good and bad decisions in different situations (Ćorić \& Jelavić, 2009). The literature also notes that a business strategy has to be ethical because a strategy which is completely or only partially morally incorrect has a bad influence on the employees' character while an ethical strategy enables good business and is mostly in the interest of the shareholders. Ethics implies moral judgments and thus it is influenced by culture and its judgment is based on moral standards applied by different cultures. This can be a problem for the multinational banks that operate across boundaries. The absence of ethical elements often 
undermines organizational cohesion and human confidence (Bogdanovic, 2008). Ethics and morality are often used interchangeably. Morality is a group of unwritten rules and customs governing interpersonal relationships (Bozovic, 2007). Ethics as the study of morality investigates the meaning and goals of moral norms and establishes the criteria for moral evaluation. Krummeck (2000) says ethical values should be a critical part of the business strategy so as to prevent and detect problems with fraud, commitment, communications control and culture. To correctly establish enduring ethical values, employees must be given the opportunity to engage with the ethics document and to discuss, examine and question the values of the organization that are placed before them (Aydinlik, Donmez, Svensson, Wood \& Callaghan, 2008).

One way of communicating and asserting ethical values in an organization is through a well-defined ethical policy. A code of ethics as well as a code of conduct is means through which ethical values can spread throughout the organization. McFadden (2010) believes that a code of conduct are derived from a code of ethics, whether the ethical code is a written or unwritten code, and that it must be understood by the members of the organization developing the code. The code of ethics and the code of conduct become instruments to safeguard institutions' standards and reputations. Both instruments inform employees of what is considered acceptable professional behaviour, and set out legal policies that affect the organizations' workers, thus reducing litigation and corporate image damage, as well as dishonest behaviour, if the codes are signed by the employees and effectively implemented by management. The effectiveness of the corporate codes of ethics is dependent on the day-to-day behaviour of the managers. The basic ethical principles in banks are principles of mutual trust, mutual benefit and interest, good intentions, business compromise and business tolerance, ethical improvement of business behaviour, de-emphasis of one's own position and conflicts between one's own interests. The Josephson Institute (2010) suggests that some of the ethical dimensions which companies could follow to increase their productivity, employee satisfaction and enhance their core values are putting the mission first - above personal consideration - and using a common language of values to increase mutual understanding. It was also emphasized that it is important to make sure the organization lives up to the employees' values, develop a code of ethics program and set the example by making ethics decisions in groups, foster transparency and trust, strengthen the business ethics skills and pay attention to detail.

Hence most of the works in the literature emphasized the need for ethical banks (Lins \& Wajnberg, 2007; Icke, Caliskan, Aytark \& Icke, 2011; San-Jose, Retola \& Gutierrez, 2009; Ćorić \& Jelavić, 2009). Ethical banks are financial institutions providing both social and economic profitability for the society and the environment. If banks conduct their intermediation function well, then the deposit and credit demands can be achieved at a reasonable cost and this will benefit all parties involved as well as the economy in general. Lins and Wajnberg (2007) assert that ethical banks offer alternative financing for socio-environment projects including attractive interest rates, longer terms or discounts in principal which improves the environment and communities as well as the economic-financial performance of the institutions. Icke, Caliskan, Ayturk and Icke (2011), corroborating the assertion of Lins and Wajnberg, state that ethical banks as financial institutions provide both social and economic profitability for the society and environment. Ethical banks are expected to invest their funds in projects with positive social value added and not in speculative projects or ineligible projects, as well as to lend funds in a fair manner without excluding any group. Akman (2011) highlights the keywords as trust, reputation and moral obligation.

However, Clegg, Kornberger and Rhodes (2007: 111) contest that "ethics is a practice of choice and evaluation circumscribed by socially established ethical models that never fully guide moral conduct". They advance three reasons for this: "First, where a person's actions are fully determined by pre-determined external criteria, then moral agency is denied to that person, even if that agency is only directed towards the choice of one model over another. Second, in practice, people encounter a plurality of ethical models for conduct that are necessarily consistent with each other, such that to follow one model might always be a means of disregarding another. Third, amidst the volatility of practice, novel situations can never entirely be predicted or captured by the model". They conclude that some interpretation is always required in order to make decisions about moral conduct and that in ethical practice there will always be at least a residue of moral agency. Dean (1999) concludes by stating that the relation and translation between rules and the use of rules reveals an analytical space in which ethics as practice becomes visible. Practitioners however find it more convenient to engage in unethical behaviour to make undue gains for themselves. Mitchell, Lewis and 
Reinsch Jr. (1992) suggest 17 categories of unethical behaviour associated with banking: honesty (lies and deception, theft and bribery), integrity (espionage, fraud and abuse), social responsibility (environmental harm, safety and invasion of privacy) and accountability and fairness (conflict of interest, insider trading, unfair trade practices and bad judgment in management decision). Carse (1999) argues that bribery and corruption is one of the main causes of banks' failure. Hauri (2000) further states some other unethical behaviours of the banks as bribery, misuse of authority and exploitation, connected lending (Hoening, 1999), lack of transparency (Coskun, 2001) and political interferences.

Overview of the Selected Nations' Ethical Banking Activities: This section looks at the ethical banking activities of the nations' under study, which are: Turkey, Croatia, Pakistan, Cyprus, Kenya and Nigeria. These nations were examined because of the high incidence of reported ethical issues, bank failures and also in appreciation of the volume of literature available on the ethical banking activities in these nations. In Turkey, banking activities have been performed by both state-owned banks and private sector banks. The ownership structure of the private sector banks varies from domestic to foreign ownership and in some cases joint ownership (Icke, Caliskan, Aytark \& Icke, 2011). This ownership structure might have helped its ability to prevent bank failures in the event of the 2007 to 2009 global financial crisis (Baum, Caglayan \& Talavera, 2010). However, the Turkish banks had its first and second financial crisis in 1994 and 2001 and apart from the introduction of deposit insurance schemes, a rehabilitation program was introduced to restructure stateowned banks (banks that were taken up by the Savings and Deposit Insurance Fund [SDIF]), to strengthen the financial position of private banks and to improve the regulatory and supervisory framework. And the banks have been found to have responded positively, with an improvement in bank and cost efficiency (Fukuyama \& Matousek, 2011). Icke et al. (2011) reports a growth rate of $13 \%$ with 10 of the 32 deposit banks having a higher growth rate than the average in the sector. Profitability and capital adequacy were respectively $19.7 \%$ and $19.3 \%$ in growth and there was a reduction in the value of non-performing banks. The approved code of ethics for banks was published in 2006 with the intention of ensuring honest, impartial, reliable and transparent banking with visible social benefits and respect for the environment, the reduction or eradication of the laundering of crime-originated assets and the prevention of the use of insider information to ensure good relationships between banks and their customers.

A CEO of one of the major banks in Croatia, Willam Mkenna, opines that the main corporate values and culture that the Croatians banks should promote are: integrity, loyalty, honesty, fairness, customer responsiveness and standard of equality. The financial institutions in the Republic of Croatia are divided into three main groups, namely banks, savings banks and housing saving banks and their initial capital is not less than HRK40 million for the banks, less than HRK8 million for the savings banks and less than HRK20 million for the housing saving banks. According to the Croatian National Bank (2010a; 2010b), there are three major banks: small banks (disposable assets of HRK1 billion), medium banks (HRK1-10 billion) and large size banks (exceeding HRK10 billion). About $82.7 \%$ of the total bank assets belonged to the group of large banks, and at the end of 2009 the banks have their ownership structure spread across the European bloc, Austria (60.4\%), Italy (19.4\%) and France (7.3\%)(Croatian National Bank, 2009). The top ten banks have the highest concentration of assets, credits and deposits. The Croatian National Bank (2010b) revealed a decrease in profits for the first quarter of 2010 with lower values in return on average assets and a return on the average equity in 2009.

There are two major banks in Pakistan: conventional banks and Islamic banks. The Pakistan Islamic banking is growing rapidly. Islamic banking is seen as focusing on customer satisfaction and making progress at a desirable rate. The number of account holders has increased by $200 \%$ since 2005 with an approximate $81 \%$ increase in 2007 alone as compared to 2006 (Khan, 2002). The banks in Northern Cyprus consisted of 25 local and foreign banks (Safakli, 2007). Foreign branch banks comprised of 6 of the 25 banks (26.08\%), 25 foreign branches exist amongst the total of 131 branches (19.08\%) with 269 banking personnel out of the 2,297 (11.71\%). And the foreign banks have $31.11 \%$ of the total assets, $33.27 \%$ of the total deposits and $5.29 \%$ of the total credits (TRNC Central Bank, 2006). Kenya's financial system has been reported to witness several unethical practices and this has been found to affect the system. Brennan (2003) asserts that the loan system in Kenya's financial system is only meant to raise money that can generate income for the banks, with the result that the banks in Kenya are individual-centered rather society-centered, dismissing the practice of ethical banking. 
The Nigerian banking industry has witnessed different phases through changes in regulatory policies and mechanisms. The unethical conduct in the industry became pronounced at the advent of the N25 billion recapitalization policy on December 31,2005. After the liberalization policy was implemented, the industry experienced a radical change from an era of only four major banks to 105 banks. However, competition weeded out some of the banks who were merely set up to trade in foreign exchange and to make huge profits for themselves while they contribute little or nothing to the societal development. This reduced the number of the banks from 105 to 89 . And in the wake of the recapitalization era, they were reduced to 25 . The introduction of the functional and regionalization policy has finally reduced the number to 20. Ikpefan and Ebai (n.d) attribute the major unethical practices of the Nigerian banks that had constantly led to the reduction in the number of the banks to the introduction of new regulatory policies. These policies were the use of customers' deposits for speculation and keeping the proceeds for personal use, the deliberate and wrongful calculation of interest payable on customer savings, the wrongful use of customers' deposits for purchasing foreign exchange at a discount, taking bribes, gifts and favours to manipulate bank functions, collusion with armed robbers to attack the bank for a commission, the imposition of excessively stringent loan conditions, prostituting by female staff to win accounts, abuse of general expense accounts, advance fee fraud, cheque kiting, account opening malpractice and dud cheques. Sanusi (2010) identifies eight factors that led to the creation of an extremely fragile financial system which was easily overran by the global crisis and financial recession: macroeconomic instability caused by large and sudden capital inflows, major failures in corporate governance at banks, lack of investor and consumer sophistication, inadequate disclosure and transparency about the financial position of banks, critical gaps in regulatory framework and regulations, uneven supervision and enforcement, unstructured governance and management processes at the Central Bank of Nigeria (CBN) and weaknesses within the CBN as well as in the business environment.

Determinants of Ethical Banking: Icke et al. (2011) establish the ethical banking practice of Turkish banks by using location assets and avoidance factor. They opine that companies doing business in the education, health and culture sectors provide higher social value added to the society than the companies doing business in other sectors. They find that the Social Value Added Lending (SVA-L) ratio is higher by function than by ownership while the Avoiding Social Exclusion Lending (ASE-L) is higher by ownership structure of the banks. In the same work, the bank managers rated legitimacy, honesty, professionalism, responsibility, consciousness and competency as the major important variables of their work. However, honesty, consciousness, responsibility, improvisation, objectiveness and professionalism are rated low, while there is a high practice of corruption, mobbing, unequal terms in hiring, discovering business secrets and the use of alcohol and other stimulants. In line with the work of Icke et al. (2011), Tea-Golja and Krstinic-Nizic (2011) find that honesty, the managers' consciousness and health protection are most important. They believe that ethical dilemmas mostly appear on stakeholder and social levels which cannot be directly affected by the organization but depend on the level of ethics existing in the society where the banks are situated. Sixty percent of the managers sampled by Tea-Golja and Krstinic-Nizic (2011) in Croatian banks see security of employees, bribery and corruption, protection of owners/shareholders and responsibility of legislation or regulation adherence as being very important issues confronting the banks.

A suggestion was further made that the code of ethics used in Croatian banks in the future should involve elements such as: international business practices, management responsibilities, rights and responsibilities of employers and employees, fundamental honesty, internal communication, equal opportunity and affirmative action, the elimination of sexual and other harassment and poor service quality. Other elements are ethical issues in marketing, advertising, accounting, expense accounts, corporate citizenship and a responsibility to society and protecting the environment. They also argue that leaders must be able to lead by example. Many researchers (for example Adnan, Saher, Naureen, Qureshi \& Khan, 2013; Alawiye-Adams, 2012; Akman, 2011; Ozkangunay \& Hortacsu, 2011; Ram, Khoso, Jamali \& Shaikh, 2011; Bozvoic, 2007; Clegg, Kornberger \& Rhodes, 2007) tend to agree on some factors that influence ethical practice. They also believe the following factors are the major components of ethical practice: honesty, trust, efficiency, helpfulness, transparency, social focus, impartiality, respect for the environment, objectivity, leadership, quality service, customer focus, confidentiality, impartiality, consistency, open-mindedness, integrity and awareness. In a separate study using 500 and 350 respondents by Ram et al. (2011) and Adnan et al. (2013), the evaluation of the ethical values of successful bankers across Pakistan banks revealed that the leaders' characteristics, the organizational characteristics and the sales force characteristics have positive impacts on ethical behaviour, 
while an authentic leadership style and job security are negatively related to ethical behaviour, and that the private banks in Pakistan are not customer friendly. These results are similar to the summary of Safakli (2007) on the evaluation of ethical behaviour in Cyprus.

\section{Methodology}

To test the determinants of ethical banking across nations, we conducted a meta-analysis of prior studies on the determinants of ethical banking. Meta-analysis is a statistical technique that can be used to quantitatively summarize the results of multiple primary studies (Junni, Sarala, Taras \& Tarba, 2013; Arthur, Bennett \& Huffcutt, 2011). The merits of using meta-analysis include the ability to summarize large bodies of literature, to examine relationships not investigated in original primary studies, to correct for study artefacts, to test the effects of various moderators and to uncover not too visible trends that may not have been detected by other approaches to summarizing research findings (Hunter \& Schmidt, 2004). We used both electronic and manual searches to identify the relevant studies (Cooper, 2010). The electronic search was conducted through yahoo search, EBSCO, JSTOR and web services. Then we manually reviewed the reference sections of all the identified studies to find additional work on the determinants of ethical banking. Both published and unpublished, quantitative and qualitative studies on determinants of ethical banking were eligible (Lipsey \& Wilson, 2000) as long as they were both quantitative and qualitative means of the determinants.

The emerging meta-analytic database was divided into three datasets. Dataset I included studies that reported the Social Value Added Lending (SVA-L) ratio (calculated by relating total credits, including noncash credits, to the social value added creating sectors - i.e. education, health and culture divided by monthly total credits), the Avoiding Social Exclusion Lending (ASE-L) ratio (calculated as the ratio of monthly total credits including non-cash loans by the banks to microenterprises mostly exposed to social exclusion divided by monthly total given credits), level of Job Security (JS), Leadership Style (LS), Sales-force Characteristics (SC), Ethical Organizational Dimension (EOD), Ethical Cognitive Dimension (ECD), Ethical Affective Dimension (EAD) and Ethical Practice/Behaviour (EP). The second dataset revealed the evaluation of ethical compliance and unethical practice and the statistical difference. The final dataset comprised of Value System (VS), Loan Effectiveness (LE), Equality in Service Provision (ESP) and Social Factors (SF) as determinants of ethical practice. Hunter and Schmidt's (2004) meta-analysis procedures were adopted by integrating a body of relevant evidence and correcting the influence of statistical artefacts. We determined some values of the variables through content analysis and investigated the relationship between the variables using correlation and simple regression.

\section{Result and Discussion}

The results obtained after the analysis of the dataset are presented in this section.

Table 1: Dataset I - The moderating effects of Job Security (JS), Leadership Characteristics (LS), Sales-force Characteristics (SC), Ethical Organizational Dimension (EOD), Ethical Cognitive Dimension (ECD) and Ethical Affective Dimension (EAD) on the relationship between Social Value Added Lending (SVA-L), Avoiding Social Exclusion Lending (ASE-L) and Ethical Practice (EP)

\begin{tabular}{lllllclll}
\hline $\mathbf{a}$ & $\mathbf{b}$ & $\mathbf{c}$ & $\mathbf{d}$ & $\mathbf{e}$ & $\mathbf{f}$ & $\mathbf{g}$ & $\mathbf{h}$ & $\mathbf{i}$ \\
.013 & .052 & 3.66 & 3.72 & 3.71 & 2.34 & 2.73 & 1.65 & 3.12 \\
.011 & .051 & 3.73 & 3.81 & 3.63 & 2.32 & 2.71 & 1.62 & 3.74 \\
.012 & .067 & 3.83 & 3.52 & 3.80 & 2.29 & 2.66 & 1.55 & 3.82 \\
.022 & .071 & 3.62 & 3.70 & 3.88 & 2.38 & 2.68 & 1.46 & 3.66 \\
.017 & .077 & 3.51 & 3.63 & 3.62 & 2.40 & 2.77 & 1.60 & 3.41 \\
.010 & .088 & 3.22 & 3.31 & 3.78 & 2.42 & 2.72 & 1.77 & 3.01 \\
\hline
\end{tabular}

Where $\mathrm{a}=$ SVA-L, $\mathrm{b}=$ ASE-L, $\mathrm{c}=\mathrm{JS}, \mathrm{d}=\mathrm{LS}, \mathrm{e}=\mathrm{SC}, \mathrm{f}=\mathrm{EOD}, \mathrm{g}=\mathrm{ECD}, \mathrm{h}=\mathrm{EAD}, \mathrm{I}=\mathrm{EP}$ 
Table 2: The moderating effects of Job Security (JS), Leadership Style (LS), Sales-force Characteristics (SC), Ethical Organizational Dimension (EOD), Ethical Cognitive Dimension (ECD) and Ethical Affective Dimension (EAD) on the relationship between Social Value Added Lending (SVA-L), Avoiding Social Exclusion Lending (ASE-L) and Ethical Practice (EP)

\begin{tabular}{|c|c|c|c|c|c|c|}
\hline \multirow{2}{*}{$\begin{array}{l}\text { Variable } \\
\mathbf{r}\end{array}$} & \multicolumn{3}{|c|}{ Main relationships } & \multicolumn{3}{|c|}{ Moderated relationship } \\
\hline & $\alpha$ & $\mathbf{R}^{2}$ & & Moderators & $\mathbf{r}$ & $\alpha$ \\
\hline \multirow[t]{2}{*}{ SVA-L } & .265 & .051 & & JS, LS, SC & .353 & .047 \\
\hline & & & 278 & EOD, ECD, EAD & .953 & .020 \\
\hline ASE-L & -.352 & .020 & & JS, LS, SC & -.700 & .050 \\
\hline EOD, EC & CD, EAD & -.368 & .040 & & & \\
\hline
\end{tabular}

Table 1 shows the data set of Job Security (JS), Leadership Style (LS), Sales-force Characteristics (SC), Ethical Organizational Dimension (EOD), Ethical Cognitive Dimension (ECD) and Ethical Affective Dimension (EAD) on the relationship between Social Value Added Lending (SVA-L), Avoiding Social Exclusion Lending (ASE-L) and Ethical Practice (EP) for the nations, arranged in this order: Turkey, Croatia, Pakistan, Cyprus, Kenya and Nigeria. Cyprus has the highest Social Value Added Lending (SVA-L) ratio while Nigeria has the highest Avoiding Social Exclusion Lending (ASE-L) ratio. The relationship between the Social Value Added Lending (SVA-L) ratio and Ethical Practice (EP) is at a .05 level of significance, which means that ethical practice relates positively with the lending of banks to the social sector across the nations studied. The more ethical a bank is in its operations, the more likely it lends to sectors that could help the economic growth and development of the nation (Icke et al., 2011; Barbu \& Boitan, 2009). While ethical practice relates negatively with Avoiding Social Exclusion Lending (ASE-L), which means the more a bank is ethical in its approach, the less it tends to lend to non-socially relevant sectors, this is consistent with the findings of Icke et al. (2011) and in line with the arguments of Baranes (2009), Bogdanovic (2008) and Carse (1999). Job security, leadership style and sales-force characteristics affect the relationship between the Social Value Added Lending (SVA-L) ratio and Ethical Practice positively as the moderated relationship coefficient is higher than the main relationship $(r=.353>.265)$, which means good leadership and fitting characteristics of the sales team as well as job security help in enhancing the Social Value Added Lending (SVA-L) ratio and Ethical Practice relationship. This contradicts the findings of Adnan, Saher, Naureen, Qureshi and Khan (2013) who argues that job security has a negative moderating effect on Ethical Practice. Our results may not be sound enough to totally dismiss Adnan et al. (2013) findings because we did not look at the individual effects of the variables. But generally, our position is supported by Hortacsu and Nur Ozkan Gunay (2004), Kjonstad and Willmott (1995), Lins and Wajnberg (2007) and Mitchell, Lewis and Reinsch Jr. (1992). The Ethical Organizational Dimension (EOD), Ethical Cognitive Dimension (ECD) and Ethical Affective Dimension (EAD) have a greater moderating effect on the SVA-L-EP relationship with $r=.953>.265$, almost a four times moderating effect on the main relationship between the Social Value Added Lending (SVA-L) ratio and Ethical Practice. This is so because Ethical Organizational Dimension (EOD), Ethical Cognitive Dimension (ECD) and Ethical Affective Dimension (EAD) define the actual environment of Ethical Practice (EP).

The moderating effects of job security, leadership style and sales-force characteristics is $r=-.700$, which is lower than the coefficient of the main relationship $r=-.352$, which means good leadership and an ethically minded sales force will discourage lending to the non-social sector. The moderating effect of Ethical Organizational Dimension (EOD), Ethical Cognitive Dimension (ECD) and Ethical Affective Dimension (EAD) is also depressing as it reduces the coefficient of relationship from $r=-.352$ to -.368 , which means creating an effective ethical environment or code of ethics, in-house ethics training, ethics code knowledge, effective coverage of the bank law, monitoring the impact of ethical values with an overlap of the bank's and managers' ethical values, that help in decreasing the emphasis of lending to non-social sectors, just as positive orientations will align strongly with Ethical Practice (Mathenge, 2013; McKinsey, 2010; Krummeck, 2000; Kjonstad \& Willmott, 1995; Bozovic, 2007). And the $\mathrm{R}^{2}$ denotes that $27.8 \%$ of variations in Ethical Practice in these nations are caused by banks' involvement in either predominant Social Value Added Lending (SVA-L) or Avoiding Social Exclusion Lending (ASE-L). 
Table 3: Dataset II - Ethical compliance and unethical practice

\begin{tabular}{|c|c|c|c|c|}
\hline \multicolumn{3}{|c|}{ Ethical compliance score } & \multicolumn{2}{|l|}{ Unethical practice score } \\
\hline 1. & Honesty & 60 & Corruption & 100 \\
\hline 2. & Knowledge & 67 & Mobbing & 80 \\
\hline 3. & Efficiency & 70 & Ensuring credit worthiness & 20 \\
\hline 4. & Punctuality & 80 & Delays in sanctioning loans & 50 \\
\hline 5. & Helpfulness & 52 & Concealment of facts & 70 \\
\hline 6. & Transparency & 20 & Overall evaluation of collateral & 70 \\
\hline 7. & Trust & 67 & Ignoring guideline $\mathrm{s}$ & 14 \\
\hline 8. & Impartiality & 62 & Unequal terms in hiring & 60 \\
\hline 9. & Social focus & 53 & Diversion of loans & 70 \\
\hline & Refraining from misinformation & 69 & Approval of false financing document & 60 \\
\hline 11 & Respect for environment & 44 & Evil nexus with customers & 48 \\
\hline & Not committing illegal actions & 67 & Non assessment of investment risks & 40 \\
\hline & Objectivity & 71 & Diversion of loans & 50 \\
\hline & Confidentiality & 73 & Use of business secrets illegally & 53 \\
\hline 15 & Consistency & 71 & Overestimation of revenue & 51 \\
\hline 16 & Open-minded & 68 & Ignoring account status of customers & 10 \\
\hline & Quality of service & 64 & Illegal service & 40 \\
\hline & Customer focus & 70 & Undue influences on customers & 45 \\
\hline
\end{tabular}

Table 4: One sample statistics of the ethical compliance and unethical practice

\begin{tabular}{lllll}
\hline & $\mathbf{N}$ & Mean & Std. deviation & Std. error of mean \\
\hline EC & 18 & 62.667 & 13.64249 & 3.21557 \\
UP & 18 & 51.7222 & 22.72807 & 5.35706 \\
\hline
\end{tabular}

Table 5: One sample test of the ethical compliance and unethical practice

\begin{tabular}{lllllll} 
& \multicolumn{2}{c}{ Test value = } \\
& $\mathbf{t}$ & df & Sig (2-tailed) & $\begin{array}{l}\text { Mean } \\
\text { difference }\end{array}$ & \multicolumn{2}{l}{$\begin{array}{l}\text { 95\% Confidence interval } \\
\text { of the difference } \\
\text { Lower }\end{array}$} \\
& & & & & Upper \\
\hline EC & 19.489 & 17 & .000 & 62.66667 & 55.8824 & 69.4509 \\
& & & & & & \\
UP & 9.655 & 17 & .000 & 51.72222 & 40.4198 & 63.0246 \\
\hline
\end{tabular}

Table 3 shows the summary level of ethical compliance and unethical practices by the banks in Kenya, Pakistan, Turkey, Cyprus and Nigeria as reported by different studies, like Adnan et al. (2013), Kman (2011), Alawiye-Adams (2012), Barbu and Boitan (2009), Baum, Caglayan and Talavera (2010), Chami and Fullenkamp (2002), Clegg, Kornberger and Rhodes (2007), Corić, and Jelavić (2009), Cowton (2002), Fukuyama and Matousek (2011), Hauri (2000), Hortacsu and Nurockan (2004), Mathenge (2013), McFadden (2010), Mitchell et al. (1992), Ozbek et al. (2012), Ram et al. (2011), Safakli (2007), San Jose and Retolaza (2008) and San-Jose et al. (2009). The table indicates the countries' rating of ethical compliance and unethical practice, with corruption scoring high in all the countries and honesty, trust, impartiality and social focus in the same range. Statistical analysis in tables 4 and 5 show a significant difference between ethical compliance and unethical practice which denotes that a country cannot be ethically compliant and be unethical at the same time. Banks that operate double standards cannot be said to be ethical. Clegg, Kornberger and Rhodes (2007) and Bozovic (2007) assert that ethics can appear incommensurate with management practice that is not following predefined judgments, but a dynamic real time interaction in relation to local culture and industry specific contexts. It implies that the ethical practice that emerges from a bank cannot be separated from the bank, and it further supports the results of this finding that a bank cannot be ethical and unethical at the same time because there is a significant statistical difference between ethical compliance and unethical practice, irrespective of residue of moral agency predicted by Clegg, Kornberger and Rhodes (2007). 
Table 6: Dataset III - Other determinants of ethical practice

\begin{tabular}{lccc}
\hline Value system & Loan effectiveness & Equality in service & Social focus \\
\hline 0.288 & 0.271 & 0.272 & 0.310 \\
0.201 & 0.164 & 0.101 & 0.110 \\
0.298 & 0.277 & 0.283 & 0.311 \\
0.318 & 0.317 & 0.313 & 0.317 \\
0.217 & 0.196 & 0.109 & 0.127 \\
0.098 & 0.165 & 0.318 & 0.082 \\
\hline
\end{tabular}

Table 7: The relationship between value system, loan effectiveness, equality in service, social focus and ethical practice

\begin{tabular}{lrrr}
\hline Variables & $\mathbf{r}$ & $\boldsymbol{\alpha}$ & $\mathbf{R}^{2}$ \\
\hline VS & .589 & .021 & \\
LEF & .283 & .051 & .366 \\
ES & -.300 & .052 & \\
SF & .303 & .053 & \\
\hline
\end{tabular}

The relationship between banks' value systems and ethical practice is moderately strong and positive; (From dataset III/Table 6 and 7) it is the highest amongst other factors, while it is negative for equality in service. The $\mathrm{R}^{2}$ shows that a $36.6 \%$ variation in ethical practice is caused by these factors. This result lays credence to the fact that the value system and social focus of banks are often predicated on ethical practice. This concurs with the arguments of Bozovic (2007), Carse (1999), Chami and Fullenkamp (2002) and Clegg, Kornberger and Rhodes (2007).

\section{Conclusion}

The ethical practice in banks vary from nation to nation, however, there seems to be an emerging trend across nations. This study collated results of studies across six nations and establishes the relationships that exist between the different variables and ethical practice. From the results it is apparent that relationships exist between the Social Value Added Lending (SVA-L) ratio and Ethical Practice (EP), and it is positively and strongly moderated by job security, leadership style and sales-force characteristics, while the combined moderating effects of Ethical Organizational Dimension (EOD), Ethical Cognitive Dimension (ECD) and Ethical Affective Dimension (EAD) are much stronger because it defines the basic environment of ethical practice. The relationship between Avoiding Social Exclusion Lending (ASE-L) and Ethical Practice is negative which denotes that it is difficult for a bank to be ethically compliant and yet support the non-social sector lending. The moderating variables have depressing effects on the relationship with reductions in the correlation coefficients. There is a significant difference in ethical compliance and unethical practice. The study concluded that it is not possible for a bank to be ethical and unethical at the same time because each one requires a specific environment. It is also noted that the value system, loan effectiveness as well as a socially focused bank is predicated on ethical practice. It is recommended that an adequate responsibility mechanism should be put in place at different banks in order to create an ethical environment, with the emphasis on the Ethical Organizational Dimension (EOD), Ethical Cognitive Dimension (ECD) and Ethical Affective Dimension (EAD) and Job Security, Leadership Style and Sales-force Characteristics, taking into account that a good value system and a socially responsive bank is predicated on well implemented ethical principles.

Key Implications \& Future Direction for Empirical Research: The variations in the practice of ethical banking across nations call for a unified standard of ethical banking practice that would serve as a good impetus for effective global banking. This would help in reducing the rate of bank failures in the industry and nations of the world. The relationship that exists between Social Value Added Lending (S-VAL) ratio and ethical practice is an indication that social lending needs to be encouraged for enhanced ethical practice with concomitant positive impact in the rate of development of nations. The moderating effects of job security, leadership style and sales-force characteristics on the social value added lending and ethical practice imply that there is need for banks to provide a work environment that would reflect a guaranteed future of their 
employees as well as encourage employees' participation in decision making. Critical evaluation needs to be done at the point of recruitment and selection to ensure that employees' characteristics and vision align with visions and missions of the banks; this is likely to forestall sharp practices that could jeopardise ethical banking as it helps in sanitizing the industry and curtails corrupt practices.

Creating an ethical environment through effective policy articulation, formulation, process, implementation and monitoring is critical for management if the rate of distress in banks would reduce and thus increasing customers' confidence and patronage. Banks must be determined to implement ethical banking if they intend to be socially focused because their involvement in unethical activities do not only disrupt the value systems but create mixed environments that cannot be sustained for a bank cannot be ethical and unethical at the same time. Processes and policies that encourage ethical banking need to be formulated by different national regulatory bodies and governments as this will support effective monetary policies and economic growth. In the light of the above, empirical study is suggested to evaluate the relationship between ethical organizational dimension, ethical cognitive dimension, ethical affective dimension and banks performance; this would help to know how ethical practices could aid performance amongst banks. And contribution of ethical banking to national development could be ascertained by assessing the relationship between Social Value Added Lending ratio of banks, economic growth and development of nations.

\section{References}

Adnan, A., Saher, N., Naureen, H., Qureshi, S. \& Khan, N. Y. (2013). What Shapes Ethical Behavior of Sales Teams? A Case Study of the Banking Sector of Pakistan. Interdisciplinary Journal of Contemporary Research in Business, 5(1), 424-442.

Akman, V. (2011). Ethics in Banking: Employees in Turkey. Interdisciplinary Journal of Contemporary Research in Business, 3(2), 251-258.

Alawiye-Adams, A. (2012). Ethics and Professionalism in Banking Services. Basic Research Journal of Business Management and Accounts, 1(1), 1-5.

Arthur, W., Bennett, W. \& Huffcutt, A. (2011). Conducting Meta-Analysis Using SAS. Taylor and Francis eLibrary.

Aydinlik, A. U., Donmez, D., Svensson, G., Wood, G. \& Callaghan, M. (2008). Communicating The Ethos of Codes of Ethics Within The Organization. Journal of Management Development, (27), 27, 778-790.

Barbu, T. C. \& Boitan, I. A. (2009). The Financial Crisis' Impact on Ethical Financial Institutions. Annals of Faculty of Economics. Retrieved October 15, 2010 from http://steconomice .uoradea.ro/anale/ volume/2009/v3-finances-banks-and-accountancy/78.pdf.

Baranes, A. (2009) Towards Sustainable And Ethical Finance. Development, 52(3), 416-420.

Baum, C. F., Caglayan, M. \& Talavera, O. (2010). Parliamentary Election Cycle and The Turkish Banking Sector. Journal of Banking and Finance, 34, 2709-2719.

Bauman, Z. \& Tester, K. (2001). Conversation with Zygmunt Bauman. Cambridge: Polity Chicago.

Beim, D. O. (2001). What Triggers a Systemic Banking Crisis? Columbia Business School Working Paper. New York: Columbia University.

Bogdanović, M. (2008). The Influencing Factors on Business System Ethics. Radovi zavoda za znanstveni rad HAZU Varaždin, 19, 295-318.

Bozovic, J. (2007). Business Ethics in Banking. Facta Universitatis Series: Economics and Organization, 4(2), 173-182.

Brennan, L. (2003). Business Etiquette for the 21st Century. London: Piatkus.

Carse, D. (1999). Speech: The Importance of Ethics in Banking. Banking Conference on Business Ethics, Hong Kong.

Chami, R. \& Fullenkamp, C. (2002). Trust and Efficiency. Journal of Banking and Finance, 26, 1785-1809.

Clegg, S., Kornberger, M. \& Rhodes, C. (2007). Business Ethics in Practice. British Journal of Management, 18, 107-122.

Cooper, H. (2010). Research Synthesis and Meta-Analysis: Astep-by-step approach. Thousand Oaks, GA: Sage Publications.

Ćorić, M. \& Jelavić, I. (2009) Ethics in Business, Ethical Leadership in the Business Context With Case Studies, Obnovljivi život, 64(2), 393-404. 
Coskun, N. (2001). The Swiss Financial Center Achievements and Challenges, Speech on Financial Excellence, pp.4.

Cowton, C. J. (2002). Integrity, Responsibility and Affinity: Three Aspects of Ethics in Banking. Business Ethics: A European Review, 11(4), 393-400.

Croatian National Bank. (2009). Annual Report.

Croatian National Bank. (2010a). Banks Bulletin, No. 20.

Croatian National Bank. (2010b). Banks Bulletin, No. 21.

Dean, M. (1999). Governmentality: Power and Rule in Modern Society. London: Sage.

Fukuyama, H. \& Matousek, R. (2011). Efficiency of Turkish Banking: Two-Stage Network System, Variable Returns to Scale Model. Journal of International Financial Markets, Institutions \& Money, 21(1), 75-91.

Hauri, K. (2000). Transnational Commercial Bribery and Corruption: A Challenge For Financial Industry Regulators and Supervisors. Eleventh International Conference of Banking Supervisors Basel, 20-21 September.

Hoening, T. M. (1999). Financial Regulators Prudential Supervision and Market Discipline: Striking A Balance. Conference on the Lesson from Recent Global Financial Crises, Federal Reserve Bank of Chicago, 1 October.

Hortacsu, A. \& Nur Ozkan Gunay, E. (2004). Ethical Issues and Attitude in the Turkish Banking Sector. MPRA Paper No: 26338. Available at: www.mpra.ub.uni-muenchen.de/26338, retrieved on 2/10/2014.

Hortacsu, A. \& Nur Ozkan Gunay, E. (2008). Vignettes to Identify The Ethical Domain of an Emerging Country's Banking Sector: The Experience of Turkey. Business Ethics: An European Review, 17(2), 121-137.

Hunter, E. \& Schmidt, F. L. (2004). Methods of Meta-Analysis: Correcting Error and Bias in Research Findings. Thousand Oaks, GA: Sage Publications.

Icke, B. T., Caliskan, E. N., Ayturk, Y. \& Icke, M. (2011). An Empirical Research of Ethical Banking in Turkey. Journal of Modern Accounting and Auditing, 7(3), 289-304.

Ikpefan \& Ebai (2014) Repositioning the Nigerian Banking Industry Through Ethics of Competitive Realities. Available at: www.hcollege.tr/pages/repos.php?p=1567, retrieved on 2/4/2014.

Junni, P., Sarala, R. M., Taras, V. \& Tarba, S. Y. (2013). Organizational Ambidexterity and Performance: A MetaAnalysis. The Academy of Management Perspectives, 27(4), 299-331.

Khan, A. M. (2002) On Trust as a Commodity and on the Grammar of Trust. Journal of Banking and Finance, 26(9), 1719-1766.

Kjonstad, B. \& Willmott, H. (1995). Business Ethics: Restrictive or Empowering? Journal of Business Ethics, 14, 445-464.

Krummeck, S. (2000). The Role of Ethics in Fraud Prevention: A Practitioner's Perspective, Business Ethics. European Review, 9(4), 268-272.

Lins, C. \& Wajnberg, D. (2007) Corporate Sustainability in the Brazilian Banking Sector. Rio De Janerio: Brazilian Foundation for Sustainable Development.

Lipsey, M. W. \& Wilson, D. B. (2000). Practical Meta-Analysis. Thousand Oaks, GA: Sage Publications.

Mathenge, G. D. (2013). The Value System of Commercial Banking in Kenya: An Ethical Perspective. International Journal of Business and Social Science, 4(1), 153-163.

McFadden, D. (2010). Code of Ethics for Banking, Available at: http://www.ehow.com /about_6576758_code ethics-banking.html.

McKinsey. (2010). Foundations of Value, Available at: http://media.wiley.com/product_data /excerpt/56/04704246/0470424656.pdf.

Mitchell, W. J., Lewis, P. V. \& Reinsch Jr., N. L. (1992). Bank Ethics: An Exploratory Study of Ethical Behaviors and Perceptions in Small Local Banks. Journal of Business Ethics, 11(3), 197-205.

Ozbek, V., Alniacik, U. \& Koc, F. (2012). The Impact of Unfair Business Practices on Bank Customers: An Experimental Study. EGE Academic Review, 12(1), 23-30.

Ozkangunay, E. N. \& Hortacsu, A. (2011). Bank Managers' Perception of Ethical and Legal Conduct in Emerging Markets During the Post Crises Period: Evidence From the Turkish Banking Sector. $B B K$ Bankacilik ve Finansal Piyasalar, 5(2), 11-49.

Ram, N., Khoso, I., Jamali, M. B. \& Shaikh, F. M. (2011). Ethical Issues in Private Commercial Banks in Pakistan. Australian Journal of Business and Management Research, 1(7), 78-82.

Rossouw, G. \& Vuuren, L. (2003). Modes of Managing Morality: A Descriptive Model of Strategies for Managing Ethics. Journal of Business Ethics, 46, 389-402. 
Safakli, O. V. (2007). Ethical Perceptions of Customers of Foreign Branch Banks in Northern Cyprus. Journal of Applied Sciences, 7(2), 294-297.

San-Jose, L. \& Retolaza, J. L. (2008). Information Transparency as a Differentiation Factor of Ethical Banking in Europe: A Radical Affinity Index Approach. The ICFAI Journal of Bank Management, 7(3), 7-22.

San-Jose, L., Retolaza, J. L. \& Gutierrez, J. (2009). Ethical Banks: An Alternative in the Financial Crisis. 22nd EBEN Annual Conference, September 10-12, Athens, Greece.

Sanusi, S. L. (2010). The Nigerian Banking Industry: What Went Wrong and The Way Forward. A Paper Presented As AConvocation Lecture at Bayero University, Kano, 26 February.

Tea-Golja, P. M. \& Krstinic-Nizic, M. (2011). Bank Commitment to Ethics. Information Management and Business Review, 3(5), 250-260.

Ten Bos, R. \& Willmott, H. (2001). Towards A Post-Dualistic Business Ethics: Interweaving Reason and Emotion in Working Life. Journal of Management Studies, 38, 769.79.

The Josephson Institute. (2010). How to Harness Ethics to Increase Productivity. Available at: http://josephsoninstitute.org/business/resources/increase_productivity.html.

TRNC Central Bank. (2006). 2005 Year report, Nicosia-Northern Cyprus, pp 33-34. 